\title{
Migrant farmers as information brokers: agroecosystem management in the transition zone of Ghana
}

\author{
Marney E. Isaac ${ }^{1,2}$, Luke C. N. Anglaaere ${ }^{3}$, Daniel S. Akoto ${ }^{4}$ and Evans Dawoe 4
}

\begin{abstract}
Environmentally induced farmer migration is an important livelihood strategy, yet little is known of the effects on the destination region agroecosystem information networks and management practices. In the forest-savanna transition zone (Brong Ahafo Region) of Ghana, where migration from northern regions (migrant) and from neighboring regions (settler) is active, we chart the role of migrant famers and the type of agroecosystem management practices embedded in information networks using a social networks approach. Based on empirical network data from 44 respondents across three communities, we illustrate a diffuse information network, with variable tie frequency between settlement categories (local, settler, or migrant) of farmers. The cohesion of this network is dependent on a few strategic bridging ties initiated by migrant farmers, who are thus centrally positioned to exchange agroecosystem management practices between geographically and socially distant groups. At the individual level, migrant and settler farmers are more likely: (1) to have larger networks with more ties between members of their networks, (2) to be brokers positioned between non-migrant farmers, and (3) to tend (although not statistically significantly) to use pro-environmental management regimes, including agroforestry practices, new planting methods, and plot-scale weeding. We conceptualize this phenomenon as extended social and environmental experience and the deployment of social-ecological memory, with migrant farmers as potential agents of innovation and adaptive management.
\end{abstract}

Key Words: agricultural innovation; agroecology; agroforestry; environmental change; Ghana; natural resource management; social network analysis; social-ecological memory; Theobroma cacao

\section{INTRODUCTION}

Challenges associated with environmental change, specifically climate change, will have significant impacts on agricultural practices, with consequences for agroecosystem productivity, biodiversity, services, and food security (Sanchez 2002, Nelson et al. 2011, Tomich et al. 2011). A decrease in rainfall has already reduced the amount of land suitable for agriculture in much of sub-Saharan Africa; with shortened growing seasons and raindependent agriculture, crop yields are expected to fall by $>50 \%$ in some of the poorest African countries as early as 2020 (Huq et al. 2003, Boko et al. 2007, IPCC 2007). Farmer migration is often reported as a strategy to cope with this gradual environmental modification (Hugo 2008, Carr 2009). Internal migration, especially inter-regional migration, has been an important direction of flow, particularly in Ghana, due to different ecological zones in the sub-region (Quartey 2009). In Ghana, within the period of 1995-2000, approximately 1.4 million people changed their district of residence (Ghana Statistical Service 2002). Various studies on migration in Ghana (e.g., Kasanga and Avis 1988, Nabila 1992, Tutu 1995, Anarfi et al. 2003, Litchfild and Waddington 2003, Ackah and Medvedev 2010, van der Geest et al. 2010) emphasize migration from the north to the central forest-savanna transition zone and coastal areas of the country as an important component of people's livelihood strategies. What is certain from empirical and theoretical research on migration, in all its varieties, is that environmental change is one of the many contributing factors, and environment-migration relationships are complex (Rocheleau et al. 1996, Carr 2005, Jonsson 2010).

Although environmental recovery and sustainable land management practices in regions of migrant origin have been explored (Olsson et al. 2005, van der Geest et al. 2010), little work has examined rural to rural migration and the role of migrant farmers in land management of the destination region. Migrant farmers possess agricultural experience from their region of origin, and this may be of increasing importance as destination regions experience their own environmental change, for instance, shifts in rainfall patterns in the transition zone of Ghana (AdjeiNsiah et al. 2010, Adjei-Nsiah and Kermah 2012). An oft-cited supposition is that migration contributes to environmental degradation in destination regions via increased population pressures or little experience in the destination ecology (Bilsborrow and Ogendo 1992, Curran 2002). Specifically, in the forest-savanna transition zone of Ghana, both Leach and Fairhead (2000) and Adjei-Nsiah et al. (2004) illustrate the mechanisms by which migrant farmers in the region negatively affect forest cover, long-term soil fertility, and fallow management. However, this has been contested more recently, as little land-use change has been reported in this destination region, presumably due to a lack of land access for migrant farmers (van der Geest et al. 2010).

Given migration in these regions, the movement of people, particularly rural farmers, will add new members to the informal and typically local social networks. Although agricultural management can occur at the individual level, in the current discourse on environmental management and social networks, importance has been placed on the dynamic nature of information sharing (Conley and Udry 2001, Bodin et al. 2006, Isaac et al. 2007). Collectively, social networks remain instrumental for the successful transfer of this information (information networks) within agrarian-based communities and provide a foundation for sustainable management. The structural characteristics of social

\footnotetext{
${ }^{1}$ Department of Physical and Environmental Sciences and Center for Critical Development Studies, University of Toronto Scarborough, ${ }^{2}$ Department of Geography, University of Toronto, ${ }^{3}$ Forestry Research Institute of Ghana, ${ }^{4}$ Faculty of Renewable Natural Resources, Kwame Nkrumah University of Science and Technology
} 
networks among land managers influences decision-making to adopt adaptive management practices and provides insight into the agency of individuals in such networks (Newman and Dale 2007, Bodin and Crona 2009, Isaac 2012, Matous et al. 2013). Increasingly, agrarian social network studies are recognized as important for elucidating adaptive capacity to vulnerability and environmental change (Tomich et al. 2011) as well as for investigating critical links between migration and environmental outcomes (Curran 2002). The introduction of new members such as migrant farmers has an as of yet undetermined influence on such informal networks.

Our primary objective was to chart the role of migrant farmers and the type of agroecosystem management practices embedded in information networks in the forest-savanna transition zone of Ghana. We posited: (1) migrant farmers have a greater capacity for pro-environmental management because of their prior agricultural experience in other, highly variable environments, and (2) such relevant experience positions migrant farmers as brokers of information in a reconfigured social space of destination regions. We draw on social-ecological memory as a framework to conceptualize our findings. Our analysis takes a social network theory and resource management approach, allowing for a balanced investigation of the social and environmental axis embedded in this research issue.

\section{METHODS}

Study region: forest-savanna transition zone of Ghana

The study took place in the Sunyani District, Brong Afaho Region of Ghana, located in the distinctive forest-savanna transition zone between the dry semi-arid north and the humid tropics of the south. This region is characterized by semi-deciduous forest and guinea savannah vegetation, with a bimodal rainfall pattern peaking in June-July and again in September-October, with a dry season in December-March. In recent years, precipitation pattern changes, land scarcity, low yields, and food insecurity in northern regions of Ghana have resulted in large-scale out-migration to more southern and western regions (Isaac et al. 2007, van der Geest 2011), including the Brong Afaho Region (Fig. 1). Local landowners previously undertook the economically important cocoa (Theobroma cacao) cultivation in the region, whereas migrant farmers composed the majority of the labor force and participated in a share-cropping system (Adjei-Nsiah et al. 2010). To the north of the study region, a decline in the cocoa industry was underway in the mid-1980s; therefore, maize and food crop (predominately maize and cassava) production increased (AdjeiNsiah and Kermah 2012). However, in the study district, located west of Sunyani, cocoa production remains quite active, and migrant farmers undertake both cocoa cultivation under a sharecropping scenario and food crop cultivation. The study location also has a large settler population originating from small-scale migration within the region or from neighboring regions with similar environmental and agricultural conditions for both cocoa and food crop production. These neighboring regions have had intermittently fewer opportunities and/or less land for cultivation, thus encouraging small-scale migration (Fig. 1).

\section{Study design}

We collected data via farmer interviews in three communities within a $20 \mathrm{~km}$ radius. These locations are similar in environmental conditions (soils, crops, climate), access to local markets, as well as having received migrant and settler farmers over the last two decades. They differ slightly in total number of households, with locality 3 being the smallest community (localities 1, 2, and 3 with approximately 40, 40, and 25 households, respectively).

Fig. 1. Generalized migration patterns within Ghana to the study area, Sunyani District, Brong Ahafo Region. Light arrows indicate migration from northern regions (Upper West, Upper East, and Northern) to the study region based on interviews; the size of the arrow indicates the magnitude of migration, with higher levels of migration from the Upper West based on van der Geest (2011). Darker arrows indicate settler farmers from neighboring regions (Eastern, Central, and Western) in southern Ghana based on a selection of interviews with farmers in the Sunyani District.

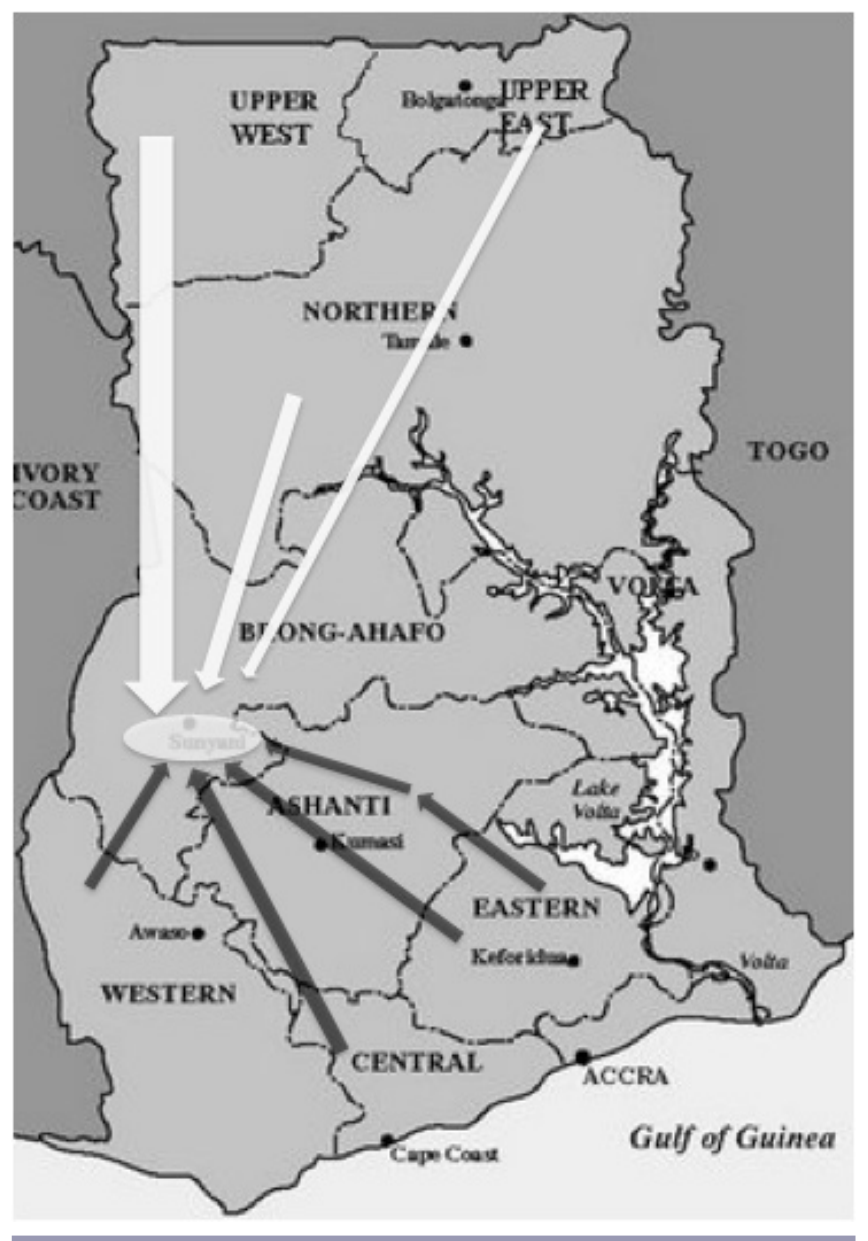

Based on previously described waves of migration, we operationalized farmer origins representing settlement categories in these communities into three categories: local, i.e., no migration; settler, i.e., post-migration farmers from neighboring regions; and migrant, i.e., post-migration farmers as environmental migrants from the north. We delineated these groups for our purposes, although clearly, variability exists within these settlement categories. For instance, migrant farmers could 
have arrived direct to the region or could have farmed in another region first.

\section{Network data collection and analysis}

We gathered network data through the name-generator technique (Marsden 2005). Informed consent was sought before any interview was conducted. Key informants guided the selection of initial interview points. These initial interview points were stratified across nine individuals in the three localities. The three starting points in each community represented one local, one settler, and one migrant respondent. A respondent was considered to be any farmer with an active farm who also plays a role in decision-making for management of the farm, thus defining both the social (farmer) and the environmental (farm) units of analysis.

Respondents were asked to list farmers from whom they seek and exchange information on land management practices, specifically agricultural practices. Subsequent interviews were conducted with all the listed individuals; these network members, all external to the household, were posed the same question to collect the names of their nominated members and so on. The end point of the name-generator collection was pre-defined; network data were collected until crossover in localities occurred and when a minimum of approximately $50 \%$ of total households in each community were interviewed. This resulted in $N=44$ individuals across the three communities. All network responses were coded as binary variables (i.e., the presence or absence of a tie), and entered into a name-based adjacency matrix (Hanneman and Riddle 2005). We analyzed the data using two units: the individual network $(N=44)$ and the aggregated network $(N=1$ with 44 members).

Individual network data were analyzed for size (number of members in an individual network, excluding the respondent), ties (number of information-sharing connections between members of an individuals network, excluding ties to the respondent), and betweenness (a measure of a respondent's centrality in their network as determined by the extent that the individual falls on the shortest path between pairs of members, normalized by the number of network members; Borgatti 2005, Hanneman and Riddle 2005). Given our research design, the number of members and ties among members in the individual networks should be treated with caution because we limited the network data collection to approximately $50 \%$ of total households in each community.

To assess respondent position within their individual network, brokerage roles in the form of consultant, gatekeeper, representative, and liaison were employed (Fig. 2). We selected these four types of brokers because each configuration includes at least one member from another category, i.e., any triad configuration that is not homogeneous. These brokerage roles indicate movement of information between individuals from different categories (Gould and Fernandez 1989). Consultants are those who transfer information from and to individuals of another category; gatekeepers are those who transfer information from individuals in one category to an individual in another category by a member of the second category; representatives are those who transfer information from individuals in one category to an individual in another category by a member in the first category; and liaisons are those who transfer information from one category to another third category (Fig. 2; Hanneman and
Riddle 2005). We determined cumulative brokerage scores for each individual.

Fig. 2. Schematic diagram of brokerage role configurations for settlement categories. (A) Consultant: transfer from one category to the same category by a member of another category. (B) Gatekeeper: transfer from one category to another by a member of the receiving category. (C) Representative: transfer from one category to another category by a member of the sending category. (D) Liaison: transfer from one category to another by a member of a third category.

A)

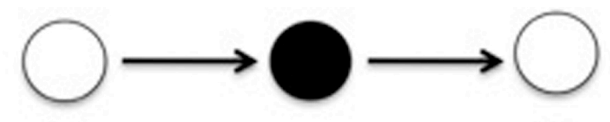

B)

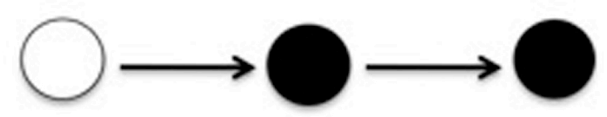

C)

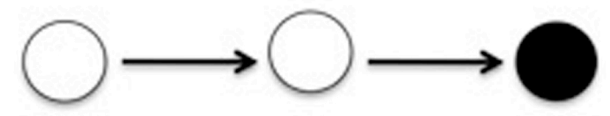

D)

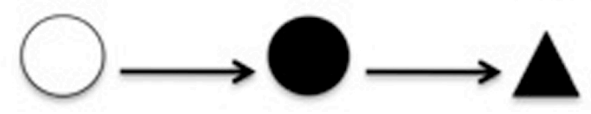

Aggregated network data were used to assess overall network cohesion as well as to visualize interactions between actors of differing communities. To do this, we analyzed for number of ties (tie frequency) within and between the three settlement categories. Because this is not a true "whole" network, we take caution in interpreting these data beyond the scope of this limited data set. All network analysis was conducted with UCINET (Borgatti et al. 2002) and visualization in Netdraw (Borgatti 2002).

Farmer attribute and agricultural management data collection Respondent demographic data were collected on age, gender, and place of birth to determine settlement status. We also gathered data on respondents' land tenure arrangement sub-grouped into three categories to further characterize farming arrangements: share-cropping (part ownership), kin ownership (parents ownership), or full ownership. These categories are based on initial interviews in the region regarding land tenure arrangements. In our data set, the range of local to migrant farmers was evenly distributed, with only $2 \%$ fewer migrant farmers (Table 1); these farmers were predominately from ethnic groups of northwestern Ghana (Adjei-Nsiah et al. 2004). The majority of respondents $(62.2 \%)$ was participating in sharecropping land tenure arrangements, with only $26.7 \%$ of respondents having full ownership over property (Table 1). Respondents were fairly evenly distributed across the three communities, with locality 3 having the lowest percentage $(20 \%)$ of respondents (Table 1). Respondents were predominately male $(73.3 \%)$ but were evenly distributed across all age categories ranging from 20 to $>60$ years of age. The duration of time spent farming in the region ranged from 1 to $50 \mathrm{yr}$, with such variability based on age and time of migration; the average amount of farming experience across respondents was $18 \mathrm{yr}$ (data not shown). 
Table 1. Respondent demographic data for the study area, Sunyani District, Brong Ahafo Region, Ghana.

\begin{tabular}{lcc}
\hline \hline $\begin{array}{l}\text { Demographic } \\
\text { characteristic }\end{array}$ & Classification & Distribution (\%) $\dagger$ \\
\hline Settlement category & Local & 33.3 \\
& Settler & 33.3 \\
& Migrant & 31.1 \\
Geographic location & Locality 1 & 42.2 \\
& Locality 2 & 37.8 \\
& Locality 3 & 20.0 \\
Land tenure status & Share-cropping & 62.2 \\
& Full ownership & 26.7 \\
& Kin ownership & 11.1 \\
\hline
\end{tabular}

$\dagger$ As a percentage of all respondents $(N=44)$.

Semi-structured interviews targeted the type of information shared between respondents, including past and current agricultural practices, agricultural history in multiple environments if appropriate, adoption of new techniques, and perceptions of environmental change. Specific questions were used to guide discussions on the use of listed management techniques that mitigate any of the mentioned environmental limitations. Techniques were determined as adaptation practices if they were described in a context of a management response to an environmental stimulus that had changed. These techniques were then categorized and analyzed for distribution among farmers.

\section{Statistical analysis}

We ran standard analysis of variance but used permutation tests to generate the significance level because our network data do not meet assumptions of independence and random sampling. We ran ANOVAs using $N=5000$ random permutations to derive significance levels of the effect of the independent attribute variable of location (locality 1-3) on network variables (i.e., network size, normalized betweenness, brokerage scores). We ran t-tests using $N=10,000$ random permutations to derive significance levels of the effect of the independent attribute variable of settlement category (two groups: no migration [local] vs. post-migration [migrants plus settlers]) on network variables (i.e., network size, normalized betweenness, brokerage scores). We tested significance levels of the aggregated tie frequency between settlement categories using ANOVA with $N=5000$ random permutations. Differences in the frequency of reported agroecosystem management practices across settlement categories were generated with ANOVAs using $N=5000$ random permutations for agroforestry management and t-tests using $N=$ 10,000 random permutations for seedling management and plant management. All tests were performed in UCINET (Borgatti et al. 2002). A contingency table was constructed for the frequency of reported adoption of agroecosystem management practices in relation to respondent attributes (settlement category); although some restrictions should be taken in interpreting the statistical outcome given the network-derived sampling, significance levels between the level of adoption across all settlement categories were generated using SAS version 9.2 (SAS Institute, Cary, NC, USA). A type I error rate was set at 0.10 for all statistical tests.

\section{RESULTS}

\section{Network structure}

At the individual level, the size of information networks varied between settlement categories (no migration/local vs. postmigration/migrants plus settlers). Local farmer networks were significantly smaller in size $(P=0.0731)$ with fewer ties $(P=$ 0.0347 ) than were networks of post-migration individuals (Table 2). The normalized betweenness values of the respondents did not differ significantly across the settlement categories. However, total brokerage scores differed significantly $(P=0.0831)$ with local farmers tending toward fewer brokerage positions (Table 2). We found that $\sim 50 \%$ of settler and migrant farmers were in brokerage roles (moving information from one group to another; Fig. 2). Only $19 \%$ of local farmers acted as brokers, exhibiting limited cross-group exchange.

Given the three localities, the size of information networks were similar but had significantly fewer ties $(P=0.0033)$ between network members in locality 1 (Table 2 ). Unlike across settlement categories, location affected the betweenness values of farmers. Respondents in localities 1 and 2 exhibited higher betweenness, more than double that of locality 3 (Table 2). Brokerage scores did not differ across the three localities.

At the aggregated network level (Fig. 3A), tie frequency decreased by $>50 \%$ when comparing number of ties between local-local interactions and local-post-migration interactions; a significantly lower number of ties was found between local-settler categories $(P=0.0410)$ and local-migrant categories $(P=0.0546$; Table 3$)$. Although not significant, the inverse occurred for migrant farmers, who exhibit the most frequent ties with settler farmers. Migrant farmers were not only linking social groups (settlement category) but also across geographic space; ties that connect communities are dominated by migrant farmers, as illustrated when community membership is overlaid on the network (Fig. 3B).

\section{Agricultural management practices}

Reported management practices ranged from integrating trees on farms, altering planting strategies, and intensified weeding practices. These practices were indicated as responses to contemporary shifts in rainfall patterns, in particular, late and reduced precipitation events. We categorized these into three groups of adaptive practices: (1) adoption of agroforestry practices as indicated by the inclusion of trees on farms, (2) adoption of nursery management as indicated by the use of seedlings over seeds as well as shifts in planting to match rainfall events, and (3) adoption of plot-scale management as indicated by increased weeding frequency (Table 4).

There was a significant difference $(P=0.0039)$ among the three agroforestry adoption levels, with all respondents reporting moderate agroforestry adoption most frequently. However, although not significantly different, only $6.7 \%$ of migrant farmers stated that they did not adopt agroforestry practices as compared to $21.4 \%$ of locals who did not report adopting agroforestry practices. Migrant and settler farmers over-represented those 
Table 2. Mean (SD) value of individual network parameters across settlement category and geographic location for the study area, Sunyani District, Brong Ahafo Region, Ghana.

\begin{tabular}{|c|c|c|c|c|}
\hline $\begin{array}{l}\text { Network } \\
\text { parameter }\end{array}$ & \multicolumn{3}{|c|}{ Respondent attribute } & $\begin{array}{c}\text { Comparison of } \\
\text { means }(P) \dagger\end{array}$ \\
\hline \multicolumn{5}{|c|}{ Settlement category } \\
\hline & No migration/local $(N=14)$ & \multicolumn{2}{|c|}{ Post-migration/settler plus migrant $(N=30)$} & \\
\hline Size & $1.9(0.70)$ & \multicolumn{2}{|c|}{$2.7(1.37)$} & 0.0731 \\
\hline Ties $\S$ & $0.1(0.35)$ & \multicolumn{2}{|c|}{$0.8(1.05)$} & 0.0347 \\
\hline Betweenness & $21.5(22.68)$ & \multicolumn{2}{|c|}{$28.7(18.65)$} & 0.3278 \\
\hline Brokerage & $0.8(1.57)$ & \multicolumn{2}{|c|}{$2.0(2.07)$} & 0.0831 \\
\hline \multicolumn{5}{|c|}{ Geographic location } \\
\hline & Locality $1(N=19)$ & Locality $2(N=16)$ & Locality $3(N=9)$ & \\
\hline Size & $2.0(1.08)$ & $2.5(1.46)$ & $2.8(1.56)$ & 0.2765 \\
\hline Ties & $0.2(0.37)$ & $0.6(0.87)$ & $1.4(1.33)$ & 0.0033 \\
\hline Betweenness & $20.2(21.57)$ & $29.6(22.9)$ & $10.1(10.95)$ & 0.0840 \\
\hline Brokerage & $1.3(1.70)$ & $2.1(2.53)$ & $1.2(1.64)$ & 0.4206 \\
\hline
\end{tabular}

$\dagger P$ values are derived from permutation tests using 10,000 random permutations for t-tests (settlement category) and 5000 random permutations for ANOVAs (geographic location).

$\dagger$ Size indicates the number of network members, excluding the respondent.

$\S$ Ties indicates connections between network members, excluding connections to the respondent.

Fig. 3. Network diagram of agroecosystem management information ties for the study area, Sunyani District, Brong Ahafo Region, Ghana. (A) All individuals, including locals, settlers, and migrants. (B) Migrants removed. The shape of the node differentiates the geographic location: circle $=$ locality 1 , triangle $=$ locality 2 , square $=$ locality 3 .

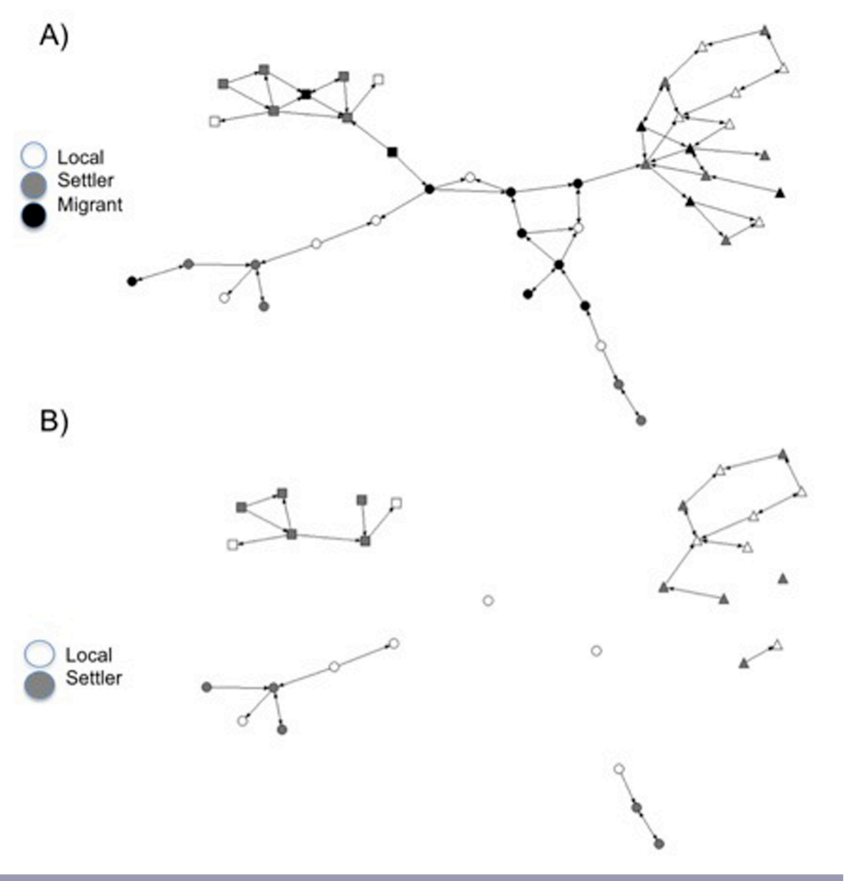

Table 3. Aggregated network tie frequency (number of ties) within and between settlement categories for the study area, Sunyani District, Brong Ahafo Region, Ghana.

\begin{tabular}{lcccc}
\hline \hline & \multicolumn{3}{c}{ Settlement category } & \\
\cline { 2 - 4 } Settlement & Local & Settler & Migrant & Total \\
category & $N=14 \dagger$ & $N=15$ & $N=15$ & $N=44$ \\
\hline Local & 6 & $4^{*}$ & $3^{*}$ & 13 \\
Settler & 8 & 11 & 7 & 26 \\
Migrant & 7 & 12 & 9 & 28 \\
\hline
\end{tabular}

$\dagger$ Number of respondents.

$* P<0.1$; significantly different than listed settlement category. Significance is derived from ANOVAs using permutation tests with 5000 random permutations.

adopting high levels of agroforestry, with double the number of respondents in the migrant category as compared to the local category reporting both fruit and timber species (Table 4). Across all three settlement categories, significantly fewer $(P=0.0050)$ respondents reported adopting planting techniques to combat low rainfall patterns; locals $(71.4 \%)$, settlers $(81.3 \%)$, and migrants $(64.3 \%)$ did not tend to adopt nursery seedlings as a method to increase survivorship under low rainfall conditions. However, more than twice as many respondents reported adopting new weeding practices at the plot scale over those that did not, and this adoption was consistently higher for postmigration farmers (Table 4). 
Table 4. Contingency table showing number $(\%)$ of respondents categorized into three settlement categories and their adoption of three identified management adaptations.

\begin{tabular}{|c|c|c|c|c|}
\hline \multirow[b]{2}{*}{ Management adaptation } & \multirow[b]{2}{*}{ Rank } & \multicolumn{3}{|c|}{ Number of respondents $(\%)$} \\
\hline & & Local & Settler & Migrant \\
\hline \multirow[t]{3}{*}{ Agroforestry adoption (integrating trees) } & None & $3(21.4)$ & $1(6.7)$ & $1(6.7)$ \\
\hline & Moderate $\dagger$ & $8(57.1)$ & $9(60.0)$ & $8(53.3)$ \\
\hline & $\operatorname{Hight}$ & $3(21.4)$ & $5(33.3)$ & $6(40.0)$ \\
\hline \multirow[t]{2}{*}{ Planting management (using nursery seedlings) } & No & $10(71.4)$ & 13 (81 3) & $9(64.3)$ \\
\hline & Yes & $4(28.6)$ & $3(18.8)$ & $5(35.7)$ \\
\hline \multirow[t]{2}{*}{ Plot-scale management (weeding) } & No & $5(35.7)$ & $4(25.0)$ & $3(21.4)$ \\
\hline & Yes & $9(64.3)$ & $12(75.0)$ & $11(78.6)$ \\
\hline
\end{tabular}

$\dagger$ Includes only fruit trees.

†Includes fruit and timber trees.

\section{DISCUSSION}

\section{Network topology}

The information networks exhibited large variability in size, ties, and betweenness, at both social (the origin of the individual) and spatial (the location of the individual) scales. Local farmers tended to have smaller individual networks, with fewer ties between members of the network, whereas settler and migrant farmer networks were almost double in size. This is not unexpected, as newer arrivals to farming communities presumably initiate new ties and activate information-seeking connections to compensate for lost ties in their region of origin, as shown in previous studies of embeddedness and tie activation (Curran 2002, Isaac et al. 2007). This higher frequency of ties by newer community members is increasingly important in environments that require a level of management knowledge (Adjei-Nsiah and Kermah 2012). Although we show such variability in individual network metrics across settlement categories, local and post-migration farmers exhibited similar betweenness scores, indicating the similar extent to which an individual facilitates communication to other members in their network (Hanneman and Riddle 2005).

\section{Importance of relationships between heterogeneous agents}

Local farmers tended to go to other local farmers more frequently, only one-half as likely to exchange information with migrant farmers. Migrant farmers, however, were more likely to exchange information with settler farmers over locals and even other migrants. We assess these exchange positions with an analysis of brokerage, the relation whereby an individual mediates information flow between two other individuals (Gould and Fernandez 1989). These roles have implications for an individual's possibility of transacting with other individuals of some of other settlement group. Operationalizing four types of brokerage at the individual level (coordinator, gatekeeper, representative, and liaison; see Fig. 2), we show that more often than not, migrant and settler farmers held brokerage positions over local farmers. Brokerage scores were higher for post-migration farmers than local farmers, indicating a higher likelihood of linking socially distant groups. Bridging ties that link across distinctive groups in a network are important in sustainable agricultural (Isaac et al.
2007) and natural resource management (Newman and Dale 2007, Bodin and Crona 2009, Prell et al. 2009). Specifically, such ties can diffuse insular management and expose network members to new and perhaps innovative techniques and practices (Klerkx et al. 2010). Here, migrant farmers are well positioned to exchange information across settlement categories in the network and presumably act as influential forces for the diffusion of agroecosystem management practices.

Communities that have strong risk-sharing informal networks have proved to be more resilient to shocks because risks can be transferred across members and time (Moser 1996, Narayan 1998, Tengö and Belfrage 2004). Although it has been shown previously that a lack of social cohesion, through migration, can decrease community resilience in the face of environmental change (Katz 2000, Pretty and Ward 2001, Entwisle et al. 2008), our study provides evidence that the introduction of new people via migration can add to the destination region's resilience. Networks limited to members that share livelihood experiences, within a bounded spatial area, may perceive environmental change equally and thus manage agricultural lands similarly. In contrast, through exposure to network members with a range of agricultural experience, individuals might change their perception of the environment and manage that environment differently.

\section{Linking adaptive management}

Diversified management practices based on local conditions are often very effective in mitigating environmental conditions and change in Ghana (Isaac et al. 2009, Westerhoff and Smit 2009, Adjei-Nsiah and Kermah 2012). Increasing biodiversity on farms can contribute to livelihood strategies under variable precipitation and other environmental risks (Tomich et al. 2011). Agroforestry, including trees in production systems, provides many environmental benefits operating at various spatial and temporal scales (Isaac and Kimaro 2011, Tscharntke et al. 2011). Further, the importance of tree biodiversity is likely to increase in the future because of the roles of on-farm trees as records of regional climate change, regulators of water and nutrient cycles, and sources of alternative income to small-scale and subsistence agriculturalists (Lin 2007, Dawoe et al. 2010, Munroe and Isaac 2014). Within our study, we report moderate levels of agroforestry within the 
study region across all settlement categories. Importantly, twice as many migrant farmers adopted high levels of tree integration as compared to local farmers. Similarly, migrant farmers proportionally tended to change from direct planting with seed to employing nursed seedlings to minimize effects of low rainfall events during periods when normal planting occurs. Migrant farmers described delaying planting for the rains based on experiences in the drier north. Such changes in planting practices have been noted as a localized adaptation to climate change in Ghana (Westerhoff and Smit 2009, Adjei-Nsiah and Kermah 2012) but rarely attributed to previous experience in another environment. Settler and migrant farmers, to a greater extent than locals, tended to intensify weeding practices to reduce water competition during periods of low rainfall. Again, migrant farmers described the necessity to reduce competition with undesirable plants based on experience in profoundly dryer regions to the north. These management practices, as reported here, are not outcome variables but attributes of the individual. While other work has demonstrated migrant adoption of local management practices (Dwyer and Minnegal 1999), we highlight that information flow could occur in the opposite direction, with migrant farmers exchanging appropriately adapted agriculture practices.

\section{Modified social-ecological systems}

The boundaries of the environmental and social space of migrant farmers are much larger, providing a more expansive toolbox for agroecosystem management strategies. Such environmental space is characterized by diverse soils, hydrology, and climate in the regions of origin and destination from which an agrarian knowledge base and successive management techniques are developed. We draw on the concept of social-ecological memory, whereby experiences are retained and integrated for innovative management (Berkes and Folke 2002, Folke 2006, Barthel et al. 2010). Presumably, the assemblage of agroecosystem information is not limited to its use in the environment of collection, but is transferred and deployed in the destination region. In this context, social-ecological memory contributes important environmental information from the recent past in other locations. Given the environmental precariousness of the transition zone of Ghana (Van der Geest et al. 2010), such social-ecological memory of migrant farmers stimulates adaptive practices in response to complexity and change. Large information networks and frequent exchange with diverse sources of information typify the social space of migrant farmers in our study. Agroecosystem management strategies can be deposited into this space for exchange, moving such information from the individual to the collective. Although this does not necessarily mean that these practices will be adopted, we argue that it is instrumental in (1) transferring practices throughout the communities because migrant farmers are positioned in key bridging roles in the network, and (2) increasing the overall community capacity for pro-environmental management. Further work is required to determine whether such mechanisms of management adaptation via new membership are reproduced in other agricultural landscapes or for other natural resources.

\section{CONCLUSIONS}

Farmer migration is often cited as an important component of livelihood strategies in response to environmental modification. Our study indicates that migrant farmers may contribute to pro- environmental management in destination regions, acting as potential agents of innovation and adaptive management practices. Although there are some limitations to the social network approach, we show that migrant farmers in the study area are centrally positioned to exchange agroecosystem management practices between geographically and socially distant groups. We conceptualize this phenomenon as extended social and environmental experience and the use of socialecological memory. Through bridging network positions and diverse environmental experience, these new members may enhance overall community adaptive management and resilience.

\section{Responses to this article can be read online at: http://www.ecologyandsociety.org/issues/responses. $\mathrm{php} / 6589$}

\section{Acknowledgments:}

We thank all participants in this research as well as L. Antwi for research support and W. Ampofo and E. Aseidu-Opoku for field assistance. We thank the anonymous reviewers for their insightful and constructive comments. This research was carried out with the aid of a grant from the International Development Research Centre, Ottawa, Canada, and a Social Sciences and Humanities Research Council of Canada Grant to MEI.

\section{LITERATURE CITED}

Ackah, C., and D. Medvedev. 2010. Internal migration in Ghana: determinants and welfare impacts. World Bank Policy Research Working Paper Series, Number 5273. World Bank, Washington, D.C., USA. http://dx.doi.org/10.1596/1813-9450-5273

Adjei-Nsiah, S., R. N. Issaka, J. O. Fening, P. Mapfumo, V. Anchirina, and K. E. Giller. 2010. Farmers' perceptions of climate change and variability and existing opportunities for adaptation in Wenchi Area of Ghana. International Journal of Climate Change: Impacts and Response 2(2):49-60.

Adjei-Nsiah, S., and M. Kermah. 2012. Climate change and shift in cropping system: from cocoa to maize based cropping system in Wenchi Area of Ghana. British Journal of Environment and Climate Change 2(2):137-152.

Adjei-Nsiah, S., C. Leeuwis, K. E. Giller, O. Sakyi-Dawson, J. Cobbina, T. W. Kuyper, M. Abekoe, and W. Van Der Werf. 2004. Land tenure and differential soil fertility management practices among native and migrant farmers in Wenchi, Ghana: implications for interdisciplinary action research. Njas: Wageningen Journal of Life Sciences 52(3-4):331-348. http://dx. doi.org/10.1016/S1573-5214(04)80020-4

Anarfi, J., S. Kwankye, O.-M. Ababo, and R. Tiemoko. 2003. Migration from and to Ghana: a background paper. Development Research Center on Migration, Globalization and Poverty, University of Sussex, Sussex, UK. [online] URL: http://r4d.dfid. gov.uk/PDF/Outputs/migrationglobpov/wp-c4.pdf.

Barthel, S., C. Folke, and J. Colding. 2010. Social-ecological memory in urban gardens - retaining the capacity for management of ecosystem services. Global Environmental Change 20(2):255-265. http://dx.doi.org/10.1016/j.gloenvcha.2010.01.001 
Berkes, F., and C. Folke. 2002. Back to the future: ecosystem dynamics and local knowledge. Pages 121-146 in L. H. Gunderson and C. S. Holling, editors. Panarchy: understanding transformations in human and natural systems. Island Press, Washington, D.C., USA.

Bilsborrow, R. E., and H. W. O. O. Ogendo. 1992. Populationdriven changes in land use in developing countries. Ambio 21 (1):37-45.

Bodin, Ö., and B. I. Crona. 2009. The role of social networks in natural resource governance: what relational patterns make a difference? Global Environmental Change 19(3):366-374. http:// dx.doi.org/10.1016/j.gloenvcha.2009.05.002

Bodin, Ö., B. Crona, and H. Ernstson. 2006. Social networks in natural resource management: What is there to learn from a structural perspective? Ecology and Society 11(2): r2. [online] URL: http://www.ecologyandsociety.org/vol11/iss2/resp2/.

Boko, M., I. Niang, A. Nyong, C. Vogel, A. Githeko, M. Medany, B. Osman-Elasha, R. Tabo, and P. Yanda. 2007. Africa. Pages 433-467 in M. L. Parry, O. F. Canziani, J. P. Palutikof, O. J. van der linden and C. E. D. Hanson, editors. Climate change 2007: impacts, adaptation and vulnerability. Contribution of Working Group II to the Fourth Assessment Report of the Intergovernmental Panel on Climate Change. Cambridge University Press, Cambridge, UK. [online] URL: http://www. ipcc.ch/publications and data/publications ipcc fourth assessment_report_wg2_report_impacts_adaptation_and_vulnerability. $\underline{\text { htm. }}$.

Borgatti, S. P. 2002. Netdraw: network visualization. Analytic Technologies, Lexington, Kentucky, USA. [online] URL: https:// sites.google.com/site/netdrawsoftware/home.

Borgatti, S. P. 2005. Centrality and network flow. Social Networks 27(1):55-71. http://dx.doi.org/10.1016/j.socnet.2004.11.008

Borgatti, S. P., M. G. Everett, and L. C. Freeman. 2002. Ucinet for Windows: software for social network analysis. Analytic Technologies, Harvard, Massachusetts, USA. [online] URL: https://sites.google.com/site/ucinetsoftware/home.

Carr, D. 2009. Population and deforestation: why rural migration matters. Progress in Human Geography 33(3):355-378. http://dx. doi.org/10.1177/0309132508096031

Carr, E. R. 2005. Placing the environment in migration: environment, economy, and power in Ghana's Central Region. Environment and Planning A 37(5):925-946. http://dx.doi. org/10.1068/a3754

Conley, T., and C. Udry. 2001. Social learning through networks: the adoption of new agricultural technologies in Ghana. American Journal of Agricultural Economics 83(3):668-673. http:// dx.doi.org/10.1111/0002-9092.00188

Curran, S. R. 2002. Migration, social capital, and the environment: considering migrant selectivity and networks in relation to coastal ecosystems. Pages 89-125 in W. Lutz, A. Prskawetz, and W. C. Sanderson, editors. Population and environment: methods of analysis. Population and Development Review, a supplement to Volume 28. Population Council, New York, New York, USA.
Dawoe, E. K., M. E. Isaac, and J. Quashie-Sam. 2010. Litterfall and litter nutrient dynamics under cocoa ecosystems in lowland humid Ghana. Plant and Soil 330(1-2):55-64. http://dx.doi. org/10.1007/s11104-009-0173-0

Dwyer, P. D., and M. Minnegal. 1999. The transformation of userights: a comparison of two Papua New Guinean societies. Journal of Anthropological Research 55(3):361-383.

Entwisle, B., G. Malanson, R. R. Rindfuss, and S. J. Walsh. 2008. An agent-based model of household dynamics and land use change. Journal of Land Use Science 3(1):73-93. http://dx.doi. org/10.1080/17474230802048193

Folke, C. 2006. Resilience: the emergence of a perspective for social-ecological systems analyses. Global Environmental Change 16(3):253-267. http://dx.doi.org/10.1016/j.gloenvcha.2006.04.002

Ghana Statistical Service. 2002. Ghana: population and housing census 2000. GHA-GSS-PHC-2000-v1.0. Ghana Statistical Service, Accra, Ghana. [online] URL: http://www.statsghana.gov. gh/nada/index.php/catalog/3.

Gould, R. V., and R. M. Fernandez. 1989. Structures of mediation: a formal approach to brokerage in transaction networks. Sociological Methodology 19:89-126. http://dx.doi. org/10.2307/270949

Hanneman, R. A., and M. Riddle. 2005. Introduction to social network methods. University of California, Riverside, California, USA.

Hugo, G. 2008. Migration, development and environment. IOM Migration Research Series 35. International Organization for Migration, Geneva, Switzerland. [online] URL: http://www.iom. int/jahia/webdav/site/myjahiasite/shared/shared/mainsite/published docs/ serial publications/MRS35 updated.pdf.

Huq, S., A. Rahman, M. Konate, Y. Sokona, and H. Reid. 2003. Mainstreaming adaptation to climate change in least developed countries ( $L C D S$ ). International Institute for Environment and Development, London, UK. [online] URL: http://pubs.iied.org/ pdfs/9219IIED.pdf?.

IPCC. 2007. Summary for policymakers. Pages 7-22 in M. L. Parry, O. F. Canziani, J. P. Palutikof, O. J. van der linden and C. E. D. Hanson, editors. Climate change 2007: impacts, adaptation and vulnerability. Contribution of Working Group II to the Fourth Assessment Report of the Intergovernmental Panel on Climate Change. Cambridge University Press, Cambridge, UK. [online] URL: http://www.ipcc.ch/publications and data/

publications ipcc_fourth_assessment_report_wg2 report_impacts adaptation and vulnerability.htm.

Isaac, M. E. 2012. Agricultural information exchange and organizational ties: the effect of network topology on managing agrodiversity. Agricultural Systems 109:9-15. http://dx.doi. org/10.1016/j.agsy.2012.01.011

Isaac, M. E., E. Dawoe, and K. Sieciechowicz. 2009. Assessing local knowledge use in agroforestry management with cognitive maps. Environmental Management 43:1321-1329. http://dx.doi. org/10.1007/s00267-008-9201-8

Isaac, M. E., B. H. Erickson, S. J. Quashie-Sam, and V. R. Timmer. 2007. Transfer of knowledge on agroforestry management 
practices: the structure of farmer advice networks. Ecology and Society 12(2): 32. [online] URL: http://www.ecologyandsociety. org/vol12/iss2/art32/.

Isaac, M. E., and A. A. Kimaro. 2011. Diagnosis of nutrient imbalances with vector analysis in agroforestry systems. Journal of Environmental Quality 40(3):860-866. http://dx.doi.org/10.2134/ jeq2010.0144

Jonsson, G. 2010. The environmental factor in migration dynamics: a review of African case studies. Working Paper 21. International Migration Institute, University of Oxford, Oxford, UK. [online] URL: http://www.imi.ox.ac.uk/pdfs/wp/wp21-jonsson.

Kasanga, R. K., and M. R. Avis. 1988. Internal migration and urbanization in developing countries: findings from a study of Ghana. Research Paper in Land Management and Development of Environmental Policy 1, University of Reading, Reading, UK.

Katz, E. G. 2000. Social capital and natural capital: a comparative analysis of land tenure and natural resource management in Guatemala. Land Economics 76(1):114-132. http://dx.doi. org/10.2307/3147261

Klerkx, L., N. Aarts, and C. Leeuwis. 2010. Adaptive management in agricultural innovation systems: the interactions between innovation networks and their environment. Agricultural Systems 103(6):390-400. http://dx.doi.org/10.1016/j.agsy.2010.03.012

Leach, M., and J. Fairhead. 2000. Challenging neo-Malthusian deforestation analyses in West Africa's dynamic forest landscapes. Population and Development Review 26(1):17-43. http://dx.doi. org/10.1111/j.1728-4457.2000.00017.x

Lin, B. B. 2007. Agroforestry management as an adaptive strategy against potential microclimate extremes in coffee agriculture. Agricultural and Forest Meteorology 144(1-2):85-94. http://dx.doi. org/10.1016/j.agrformet.2006.12.009

Litchfild, J., and H. Waddington. 2003. Migration and poverty in Ghana: evidence from the Ghana living standards survey (GLSS $I V)$. Sussex Migration Working Paper 10. Sussex Centre for Migration Research, University of Sussex, Sussex, UK. [online] URL: http://www.imi.ox.ac.uk/online-library/468.

Marsden, P. V. 2005. Recent developments in network measurement. Pages 8-30 in P. J. Carrington, J. Scott, and S. Wasserman, editors. Models and methods in social network analysis. Cambridge University Press, Cambridge, UK. http://dx. doi.org/10.1017/CBO9780511811395.002

Matous, P., Y. Todo, and D. Mojo. 2013. Roles of extension and ethno-religious networks in acceptance of resource-conserving agriculture among Ethiopian farmers. International Journal of Agricultural Sustainability 11(4):301-316. http://dx.doi. org/10.1080/14735903.2012.751701

Moser, C. O. 1996. Confronting crisis: a comparative study of household responses to poverty and vulnerability in four poor urban communities. Environmentally Sustainable Development Studies and Monographs Series 8. World Bank, Washington, D.C., USA. http://dx.doi.org/10.1596/0-8213-3562-6

Munroe, J. W., and M. E. Isaac. 2014. $\mathrm{N}_{2}$-fixing trees and the transfer of fixed-N for sustainable agroforestry: a review. Agronomy for Sustainable Development 34(2):417-427. http://dx. doi.org/10.1007/s13593-013-0190-5
Nabila, J. S. 1992. Population distribution and resource utilization in Ghana. Population Distribution in Africa, RIPS Monograph Series 7:30-83.

Narayan, D. 1998. Social capital survey in Ghana-preliminary results. Poverty Reduction and Economic Management Network, World Bank, Washington, D.C., USA.

Nelson, G. C., M. W. Rosegrant, A. Palazzo, I. Gray, C. Ingersoll, R. Robertson, S. Tokgoz, T. Zhu, T. B. Sulser, C. Ringler, S. Msangi, and L. You. 2011. Climate change: impact on agriculture and costs of adaptation and food security, farming, and climate change to 2050. International Food Policy Research Institute, Washington, D.C., USA.

Newman, L., and A. Dale. 2007. Homophily and agency: creating effective sustainable development networks. Environment, Development and Sustainability 9(1):79-90. http://dx.doi. org/10.1007/s10668-005-9004-5

Olsson, L., L. Eklundh, and J. Ardö. 2005. A recent greening of the Sahel - trends, patterns and potential causes. Journal of Arid Environments 63(3):556-566. http://dx.doi.org/10.1016/j. jaridenv.2005.03.008

Prell, C., K. Hubacek, and M. Reed. 2009. Stakeholder analysis and social network analysis in natural resource management. Society and Natural Resources 22(6):501-518. http://dx.doi. org/10.1080/08941920802199202

Pretty, J., and H. Ward. 2001. Social capital and the environment. World Development 29(2):209-227. http://dx.doi.org/10.1016/ S0305-750X(00)00098-X

Quartey, P. 2009. Migration in Ghana: a country profile 2009. International Organization for Migration, Geneva, Switzerland. [online] URL: http://publications.iom.int/bookstore/free/ Ghana Profile 2009.pdf.

Rocheleau, D., B. Thomas-Slayter, and E. Wangari, editors. 1996. Feminist political ecology: global issues and local experiences. Routledge, London, UK.

Sanchez, P. A. 2002. Soil fertility and hunger in Africa. Science 295:2019-2020. http://dx.doi.org/10.1126/science.1065256

Tengö, M., and K. Belfrage. 2004. Local management practices for dealing with change and uncertainty: a cross-scale comparison of cases in Sweden and Tanzania. Ecology and Society 9(3): 4. [online] URL: http://www.ecologyandsociety.org/vol9/iss3/art4/.

Tomich, T. P., S. Brodt, H. Ferris, R. Galt, W. R. Horwath, E. Kebreab, J. H. J. Leveau, D. Liptzin, M. Lubell, P. Merel, R. Michelmore, T. Rosenstock, K. Scow, J. Six, N. Williams, and L. Yang. 2011. Agroecology: a review from a global-change perspective. Annual Review of Environment and Resources 36:193-222. http://dx.doi.org/10.1146/annurev-environ-012110-121302

Tscharntke, T., Y. Clough, S. A. Bhagwat, D. Buchori, H. Faust, D. Hertel, D. Hölscher, J. Juhrbandt, M. Kessler, I. Perfecto, C. Scherber, G. Schroth, E. Veldkamp, and T. C. Wanger. 2011. Multifunctional shade-tree management in tropical agroforestry landscapes - a review. Journal of Applied Ecology 48(3):619-629. http://dx.doi.org/10.1111/j.1365-2664.2010.01939.x 
Tutu, K. 1995. Determinants of internal migration. In K. A. Twum Baah, J. S. Nabila, and A. F. Aryee, editors. Migration research study in Ghana. Internal Migration, Ghana Statistical Service, Accra, Ghana.

Van der Geest, K. 2011. North-South migration in Ghana: what role for the environment? International Migration 49(S1):e69-e94. http://dx.doi.org/10.1111/j.1468-2435.2010.00645.x

Van der Geest, K., A. Vrieling, and T. Dietz. 2010. Migration and environment in Ghana: a cross-district analysis of human mobility and vegetation dynamics. Environment and Urbanization 22(1):107-123. http://dx.doi.org/10.1177/0956247809362842

Westerhoff, L., and B. Smit. 2009. The rains are disappointing us: dynamic vulnerability and adaptation to multiple stressors in the Afram Plains, Ghana. Mitigation and Adaptation Strategies for Global Change 14(4):317-337. http://dx.doi.org/10.1007/s11027-008-9166-1 